\title{
Studies on the Effect of Gamma, Laser Irradiation and Progesterone Treatments on Gerbera Leaves
}

\author{
Sami Ali Metwally, ", Abd-El Rhaman Elariean Awad², Bedour Helmy Abou-Leila ${ }^{3}$, \\ Tarek Abd Allah EI Tayeb ${ }^{4}$, Ibrahem El Abasery Habba ${ }^{1}$ \\ ${ }^{1}$ Ornamental Plants and Woody Trees Department, National Research Centre, Dokki, Egypt \\ ${ }^{2}$ Horticulture Department, Faculty of Agriculture, Zagazig University, Zagazig, Egypt \\ ${ }^{3}$ Water Relations and Field Irrigation Department, National Research Centre, Dokki, Egypt \\ ${ }^{4}$ Photochemistry and Photobiology, National Institute of Laser Enhanced Sciences, Cairo University, Dokki, Egypt
}

Email address:

aly.samy88@yahoo.com (S. A. Metwally)

\section{To cite this article:}

Sami Ali Metwally, Abd-El Rhaman Elariean Awad, Bedour Helmy Abou-Leila, Tarek Abd Allah El Tayeb, Ibrahem El Abasery Habba. Studies on the Effect of Gamma, Laser Irradiation and Progesterone Treatments on Gerbera Leaves. European Journal of Biophysics. Vol. 3, No. 6, 2015, pp. 43-50. doi: 10.11648/j.ejb.20150306.11

\begin{abstract}
The present study, we aimed to evaluate the effect of progesterone (prog.) concentrations (10, 20 and $30 \mathrm{ppm}$ ), gamma rays $(\gamma)$ doses $(100,150$ and $250 \mathrm{rad})$, helium neon laser rays $(\mathrm{He}-\mathrm{Ne})$ exposure time (1.0, 5.5 and $11.5 \mathrm{~min}$.$) and argon$ laser rays (Ar) exposure time (1.0, 7.5 and $15.5 \mathrm{~min}$.) and some interaction treatments between progesterone and irradiation treatments on biochemical constituents i.e. growth regulators and some enzymes activity in gerbera leaves. For this reason, at the greenhouse of the National Research Centre, Dokki, Giza, Egypt. Pot experiments were carried out two successive seasons of 2006 and 2007, and growth regulators (IAA, GA 3 , Cytok. and ABA), some enzymes activity in gerbera leaves (POD, CAT, Alk. phosph and Acid. phosph) and protein content were determined. The results showed that, low conc. of progesterone hormone, low exposure time of argon and He-Ne laser has a great effect on increasing POD activities and Cytokine content. Gamma rays at 150 rad increased ABA, POD, CAT and Alkaline and acid phosphatase, while 250 rad increased IAA and GAlike substances. The least value of alkaline phosphatase activity was recorded by progesterone treatments.
\end{abstract}

Keywords: Gerbera, Chemical Constituents, Gamma Radiation, Laser Rays, Progesterone, Enzymes Activity, Growth Hormones

\section{Introduction}

Gerbera jamesonii flowers belong to the family compositae (Asteraceae) is one of the most important attractive cut flowers, grown through the world in wide. It is ideal for border, pots and for rock garden, and highly recommended for exportation. Much attention at different parts of world has been devoted to use steroids compounds gamma and laser treatments to improve growth and flowering. As for steroid compounds. Progesterone acts as a mammalian gronadal hormone, it is essential for continuation of early pregnancy and play important role in ovulation. Progesterone has also been reported to be present in Holarrhena floribunda leaves [1], apple seeds [2] and in pea (Pisum sativum) [3].The effect of progesterone in inducing flowering or generation development in wheat was recorded by [4] and Arabidopsis [5], Also, [6] recorded the effect of progesterone in antioxidant enzymes activity on chickpea seedlings.. As for Gamma rays belongs to ionizing radiation and interact to atoms or molecules to produce free radicals in cells. These radicals can damage or modify important components of plant cells and have been reported to affect differentially the morphology, biochemistry, and physiology of plants depending on the irradiation level. These effects include changes in the plant cellular structure and metabolism, e.g., dilation of thylakoid membranes, alteration in photosynthesis, modulation of the antioxidative system, and accumulation of phenolic compounds $[7,8,9]$. As for laser rays which belong to unionizing radiation laser is an abbreviation of Light Amplification by Stimulated Emission of Radiation. It is identified by the emitted wavelength and the power. [10] and [11] reported that the temperature rise in an irradiated tissue is proportional to light absorption in that tissue which in turn is determined by how effectively its 
constituent molecules absorb incident photons of a particular wave length.[12] reported that He-Ne laser gave good value in germination seeds of Nigella sativa L. in comparison with untreated plants. The aim of this present work is to evaluate efficiency of laser, gamma rays and progesterone on the some chemical constituents of gerbera leaves.

\section{Materials and Methods}

The current study was undertaken during two successive seasons of 2006 and 2007 at screen greenhouse of National Research Centre, Dokki, Egypt. In both seasons, for cultivation earthenware pots $30 \mathrm{~cm}^{2}$ in diameter and $50 \mathrm{~cm}$ in depth were used in this study, each pot was filled with media containing a mixture of sand plus clay as 1:2 by volume. For cultivation uniform small offshoots from healthy mother plants (Gerbera jamesonii cv. superba, yellow variety) were obtained from Zohria Garden 10-15cm length with 2-3 leaves.

In each season three types of treatments were performed which were, gamma, laser irradiation, and progesterone (Prog.) treatments. These treatments were made either single and/or in combination with progesterone treatments taking all possible combinations.

Thus the current study represented by 40 treatments including the control, in which the combination of 3 concentrations of progesterone $(10,20$ and $30 \mathrm{ppm})$ as equas solution, 3 gamma rays doses (100,150, $250 \mathrm{rad})$ and 6 laser treatments in addition to the control.

The experiment in each season comprise of (378) offshoots of Gerbera jamesonii cv. superba. The offshoots were divided into 4 different groups including the control. The first group (108 shoots) was subjected to gamma irradiation $(\gamma)$ at Middle Eastern Regional Radia Isotop Centre for Arab Countries, Dokki, Cairo, Egypt, using a $\mathrm{Co}^{60}$ source. The selected dose $(100,150,250 \mathrm{rad})$. The offshoots which were exposed to $(\gamma)$ radiation and also the control 27 offshoots (the fourth group) was transplanted on the next day at 23 March in both seasons.

The second group was used for laser treatments and their interactions comprised 216 offshoots, this offshoots were divided into two main groups for irradiation by the two laser types helium neon laser ( $\mathrm{He}-\mathrm{Ne})$ and argon laser (Ar) and each of irradiation group were sub divided again into three subgroup according to the exposure time to laser, where the exposure time for He-Ne irradiation laser was 1, 5.5 and 11.5 min. and 1, 7.5 and $15.5 \mathrm{~min}$. for argon (Ar) laser irradiation. The offshoots which exposed to laser treatments were transplanted on the next day on 26 March in both seasons.

As for our experiment helium-neon (He-Ne) lasers of power $20 \mathrm{Mw}$ ( wave length $632.8 \mathrm{~nm}$ ) and argon (Ar)laser of power $15 \mathrm{Mw}$ ( wave length $514.5 \mathrm{~nm}$ ) were used for Gerbera jamesonii cv.superba for red and green light irradiation respectively.

The third group of experiment was used for progesterone treatments in both seasons, comprised 27 offshoots this homogenous offshoots were transplanted on 23 March. The solution of progesterone in distilled water were sprayed twice, the first was 15 days after transplanting and the other four weeks later, where the spraying processes was performed early at morning using small hand atomizer. The volume of spray solution was enough to cover the plant foliage till drip, and teepol was used as a wetting agent in order to minimize the surface tension between the leaves and growth regulators. Three concentrations were used 10, 20 and $30 \mathrm{ppm}$ and control checks were made by spraying with water. Besides, Thus the experiments included of 48 treatments in which the combination of 10,20 and $30 \mathrm{ppm}$ of progesterone, 3 doses of gamma rays 100,150 and $250 \mathrm{rad}$, 1,5.5 and 11.5 He-Ne min. and Ar. Laser 1,7.5 and 15.5min. in addition to control.These progesterone concentrations were made either single or combination with other two groups, gamma and laser irradiation treatments where gamma rays or laser treatments preceded the progesterone treatments. i.e irradiation treatments followed by progesterone.

The experiment layout was arranged in completely randomized block design where each treatment replicated three times and each replicate represented by 3 pots. The plants of treatments were left under natural day light in the green house.

Daily observation was made throughout the experiments, where the fertilizers were supplied for each pot as recommended by Agriculture Research Centre, and irrigation was done with tap water according the needed amount of water. Chemical analyses were recorded.

\section{Chemical Analyses}

\subsection{Endogenous Hormones ( $\mu$ g/g.f.w.)}

At flowering stage (120) days from transplanting fresh leaves at flowering stage were sampled for detection of

For the determination of endogenous hormones for the single treatments Indol Butyric Acid (ABA), Indol Acetic Acid (IAA), Cytokinen (CK.) and GA-like substances, as $\left(\mathrm{GA}_{3}\right)$. Young leaves were sampled, weighed and immediately frozen with liquid nitrogen and stored in deep freezer (for a period not exceeding 3 weeks) until extraction and determination of endogenous hormones. The methods adapted for extraction and separation of plant growth substances in leaves of gerbera treated plants and control was that described by [13] and [14] respectively.

\subsection{Enzyme Activity (EU./g.f.wt.)}

At flowering stage young leaves of gerbera were sampled from control and treated plants to determine enzyme activity of catalase (CAT), peroxidase (POD), acid phosphatase (acid phosph.) and alkaline phosphatase (alk.phosph).The samples were weighed and immediately frozen with liquid nitrogen and stored in deep freezer (for a period not exceeding 3 weeks) until extraction and determination of the enzyme activity.

\section{Enzyme extraction}

Enzyme extraction was carried out according to the method reported by [15].

i. Catalase specific activity $\left(\mu \mathrm{mol} \mathrm{H}_{2} \mathrm{O}_{2}\right.$ consumed/mg 
protein $/ \mathrm{min})$.

Catalase (CAT) was assayed by measuring the decrease in absorbance to disappearance of $\mathrm{H}_{2} \mathrm{O}_{2}$ at $240 \mathrm{~nm}$ according to [16].

ii. Pyrogallol peroxidase (POD) specific activity

Peroxidase was assayed spectrophotometer chemically according to the method described by [17].

iii. Acid phosphatase activity

It was determined according to kinetic colorimetric method by using specific Kits were bought from FAR Srl Company.

iv. Alkaline phosphatase activity

It was determined according to Kinetic colorimetric method by using specific Kits were brought from Spectrum Company and Egyptian company for Biotechnology.

\subsection{Protein Content $(\mathrm{mg} / \mathrm{ml})$}

Protein content was determined by using the extracts of enzyme according to method described by [18].

\subsection{Statistical Analysis}

The statistical layout of this experiment was completely randomized block design. Each treatment was contained three replicates and each replicate was contained three pots.

\section{Results and Dissection}

\subsection{Effect of Progesterone, Gamma, Helium Neon and Argon Laser Irradiation on Endogenous Hormones $(\mu \mathrm{g} / \mathrm{g} / \mathrm{f} . w)$ in Leaves of Gerbera Jamesonii Plant}

\subsubsection{Indol Acetic Acid Concentration (IAA) ( $\mu \mathrm{g} / \mathrm{g} / \mathrm{f} . \mathrm{w})$}

Data in Table (1) show that, in general, progesterone, gamma rays, helium neon and argon laser rays increased IAA concentration $(\mu \mathrm{g} / \mathrm{g})$ in gerbera leaves, as compared to the control. The highest increases were obtained from progesterone at $20 \mathrm{ppm}$, gamma rays at $250 \mathrm{rad}$, helium neon at $11.5 \mathrm{~min}$. exposure and argon laser rays 15.5 and $7.5 \mathrm{~min}$. exposure. They induced 142.09\%, 42.58\%, $107.71 \%$ and $117.81 \%$ over the control in the first season, and $133.16 \%, 138.87 \%, 93.29 \%$ and $123.35 \%$ over the control in the second season respectively. In this respect, the previous results agreed with that of [18] on sunflower,[20] on wood cuttings of Robinia pseudoacacia plants by using laser radiation,[21] on gladiolus corms, [22] on faba beans by using gamma rays.

\subsubsection{Gibberellins GA-like Substances, as (GA3) ( $\mu g / g$ f.w)}

It was revealed from the data in Table (1) that, in general, the higher doses of progesterone at $30 \mathrm{ppm}$ and the moderate argon laser rays (7.5 min. exposure) showed the higher increase in endogenous gibberellins as GA-like substances concentrations in gerbera leaves, in the two seasons. They showed $0.19 \%$ and $13.82 \%$ increases over the control in the first season and $72.64 \%$ and $67.99 \%$ over the control in the second season.

The medium (150 rad) and higher (250 rad) doses of gamma rays and helium neon rays (5.5 $\mathrm{min}$. and $11.5 \mathrm{~min}$.exposure) showed higher increases in endogenous gibberellins as GAlike substances concentrations in gerbera leaves in the second season only. Whereas gamma rays induced $58.49 \%$ and $55.07 \%$ increases over the control. Helium neon laser rays induced $78.61 \%$ and $84.87 \%$ over the control in the second season. These results were confirmed by the finding recorded by [23] on rose cuttings, [21] on gladiolus corms,[22] on faba bean by using gamma rays.

Table 1. Effect of progesterone, gamma, helium neon and argon laser irradiation on endogenous hormones concentration in leaves of Gerbera jamesonii plants, during the two seasons of 2006 and 2007.

\begin{tabular}{|c|c|c|c|c|c|c|c|c|}
\hline \multirow{2}{*}{$\begin{array}{l}\text { Parameters } \\
\text { Treatments }\end{array}$} & \multicolumn{2}{|c|}{ IAA $(\mu \mathrm{g} / \mathrm{g} / \mathbf{f} . w)$} & \multicolumn{2}{|c|}{$\mathbf{G A}_{3}(\boldsymbol{\mu g} / \mathbf{g} / \mathbf{f} . w)$} & \multicolumn{2}{|c|}{ Cytok. $(\mu \mathrm{g} / \mathrm{g} / \mathrm{f} . \mathrm{w})$} & \multicolumn{2}{|c|}{ ABA $(\boldsymbol{\mu g} / \mathbf{g} / \mathbf{f} . w)$} \\
\hline & $1^{\text {st }}$ & $2^{\text {nd }}$ & $1^{\text {st }}$ & $2^{\text {nd }}$ & $1^{\text {st }}$ & $2^{\text {nd }}$ & $1^{\text {st }}$ & $2^{\text {nd }}$ \\
\hline Cont & 6.989 & 7.813 & 10.519 & 8.455 & 8.551 & 8.599 & 2.260 & 8.214 \\
\hline $\operatorname{Prog}_{1}$ & 7.743 & 7.444 & 7.449 & 7.409 & 10.891 & 10.199 & 5.819 & 8.223 \\
\hline $\operatorname{Prog}_{2}$ & 16.920 & 18.217 & 7.932 & 12.898 & 7.223 & 10.503 & 3.997 & 6.421 \\
\hline $\operatorname{Prog}_{3}$ & 9.458 & 7.987 & 10.539 & 14.597 & 9.876 & 7.499 & 3.572 & 9.111 \\
\hline$\gamma_{1}$ & 9.335 & 7.899 & 9.976 & 12.111 & 6.110 & 10.207 & 2.985 & 6.781 \\
\hline$\gamma_{2}$ & 8.251 & 13.572 & 8.653 & 13.401 & 9.532 & 15.189 & 4.556 & 9.209 \\
\hline$\gamma_{3}$ & 9.965 & 18.663 & 10.221 & 13.112 & 6.397 & 12.881 & 3.171 & 8.390 \\
\hline $\mathrm{He}-\mathrm{Ne}_{1}$ & 11.173 & 13.481 & 9.220 & 11.129 & 8.991 & 12.709 & 5.191 & 7.116 \\
\hline $\mathrm{He}-\mathrm{Ne}_{2}$ & 10.351 & 9.711 & 7.105 & 15.102 & 13.706 & 12.012 & 4.110 & 8.441 \\
\hline $\mathrm{He}-\mathrm{Ne}_{3}$ & 14.517 & 15.102 & 7.539 & 15.631 & 8.670 & 11.362 & 4.882 & 6.103 \\
\hline $\mathrm{Ar}_{1}$ & 11.945 & 13.119 & 7.228 & 12.310 & 8.108 & 15.303 & 5.874 & 8.230 \\
\hline $\mathrm{Ar}_{2}$ & 8,182 & 17.451 & 11.973 & 14.203 & 12.661 & 14.771 & 5.432 & 9.187 \\
\hline $\mathrm{Ar}_{3}$ & 15.223 & 12.532 & 8.210 & 13.761 & 8.219 & 14.109 & 6.530 & 7.991 \\
\hline
\end{tabular}

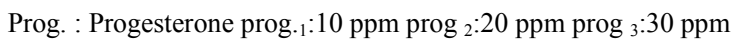

$\gamma$ : Gamma radiation $\gamma_{1}: 100 \mathrm{rad} \gamma_{2}: 150 \mathrm{rad} \gamma_{3}: 250 \mathrm{rad}$

$\mathrm{He}-\mathrm{Ne}$ : helium-neon $\mathrm{He}-\mathrm{Ne}_{1}: 1 \mathrm{~min}$. He-Ne ${ }_{2}: 5.5 \mathrm{~min}$. He-Ne ${ }_{3}: 11.5 \mathrm{~min}$.

Ar: Argon $\mathrm{Ar}_{1}: 1 \mathrm{~min} . \mathrm{Ar}_{2}: 7.5 \mathrm{~min} . \mathrm{Ar}_{3}: 15.5 \mathrm{~min}$. 


\subsubsection{Cytokinins ( $\mu \mathrm{g} / \mathrm{g} / \mathrm{f}$.w)}

Table (1) explain that, in general, the lower and medium doses (10 and $20 \mathrm{ppm}$ ) of progesterone and the medium doses of gamma rays (150 rad), helium neon (5.5 min.expousre and argon laser rays (7.5 min. exposure) increased the cytok.concentration in gerbera leaves mostly in the two seasons. Cytokinine $(\mu \mathrm{g} / \mathrm{g})$ concentration was increases to reach $27.36 \%, 11.47 \%, 60.28$ and $48.06 \%$ over the control for the first season. Whereas they were $18.60 \%$, $22.14 \%, 76.63 \%, 39.69 \%, 71.77 \%$ increases over the control in the second season.

The above mentioned findings were in harmony with [22] on faba bean by using gamma rays and [19] on sunflower by using laser rays.

\subsubsection{Abscisic Acid (ABA) ( $\mathrm{gg} / \mathrm{g} / \mathrm{f} . w)$}

Data in Table (1) show that, in general, most of the treatments induced increases in $\mathrm{ABA}$ concentration in the leaves of gerbera. The lower doses of progesterone at $10 \mathrm{ppm}$ increased ABA concentration in gerbera leaves, in the two seasons. These increases over passed the control with $157.47 \%$ and $0.109 \%$ respectively.

Gamma rays at the medium dose (150 rad) showed the higher increase in ABA concentration in the two seasons, when compared to the control treatment. It over passed the control $101.59 \%$ and $12.11 \%$ in the two seasons, respectively.

No define trend was recorded with the different kinds of laser rays. In spite of that, the medium exposure time treatments in both helium neon or argon laser rays, recorded the higher increases in ABA concentration in gerbera leaves, especially in the second season; the data of the first season were lower as compared with that recorded in the second one.

\subsection{Effect of Progesterone, Gamma, Helium Neon and Argon Laser Irradiation on Enzyme Activity and Protein in Leaves of Gerbera Jamesonii Leaves}

\subsubsection{Peroxidase (Eu/mg Protein/min)}

It is evident from Table (1) that, in general, most of the treatments increased the activity of peroxidase enzyme, compared with control.

The higher doses of progesterone (20 and $30 \mathrm{ppm})$ induced increases of peroxidase activity. Progesterone at $20 \mathrm{ppm}$ recorded the highest peroxidase activity; it gave $89.43 \%$ and $125.67 \%$ increases over the control. Progesterone at $30 \mathrm{ppm}$ dose increased peroxidase activity with lower effect, it recorded $23.65 \%$ and $22.38 \%$ increases over the control, for the two seasons, respectively.

These results are confirmed by those obtained by [24] on wheat plants using BR.and [6] on chickpea seedlings

Gamma ray at $150 \mathrm{rad}$ recorded higher peroxidase activity. The increases were $120.42 \%$ and $27.75 \%$ over the control in the two seasons. These results were confirmed by that obtained by [25] on mango plants, [26] on canola plants and
[27] on Brachypodium distachyon.

The second and the third laser rays (helium neon and argon) exposure time $(5.5,11.5 \mathrm{~min}$ and $7.5,15.5 \mathrm{~min}$. exposure) recorded higher increases in peroxidase activity.

Helium neon laser rays at $5.5 \mathrm{~min}$. exposure time recorded $73.61 \%$ and $60.71 \%$ over the control. Whereas, He-Ne $(11.5$ min. exposure) showed 66.23 and $66.44 \%$ increases over the control in the two seasons, respectively

Argon laser rays showed similar trend. Argon laser rays at time exposure $7.5 \mathrm{~min}$. gave $20.46 \%$ and $110.43 \%$ increases over the control. Whereas, argon rays at the third exposure time $15.5 \mathrm{~min}$. gave $96.06 \%$ and $32 \%$ increases over the control in both seasons, respectively.

\subsubsection{Catalase (Eu.g.f.wt)}

As shown in Table (2) that, in general, the only treatment succeeded to increase the catalase activity was that of progesterone at $10 \mathrm{ppm}$. It produced $26.10 \%$ and $50.50 \%$ over passed the control in the two seasons. The medium progesterone concentration (20 ppm), slightly lowered the catalase activity in the first season, whereas, it increased the activity in the second season. The medium concentration induced $8.53 \%$ and $3.057 \%$ lower and over the control. [24] also found the stimulatory effect on wheat plant sand [6] on chickpea seedlings

The lower dose of gamma rays (100 rad) slightly lowered catalase activity in the first season, while it increased the activity in the second seasons. It caused $3.53 \%$ decrease and $12.69 \%$ increase over the control. These results are in agreement with those reported by, [28] on grains of triticale, [25] on mango plants using gamma irradiation and [27] on Brachypodium distachyon.

Beside those treatments previously mentioned, all other treatments of progesterone at $30 \mathrm{ppm}$, gamma rays at 150 , $250 \mathrm{rad}$ and all laser treatments decreased the catalase activity. These results are in agreement with those repoted by [29] on cotton seeds, [30] on iris, [31] on potatoes plant and [32] on vicia faba under effect of gamma rays and [33] on wheat plants by using laser radiation.

\subsubsection{Alkaline Phosphatase ( $\mu \mathrm{g} / \mathrm{ml})$}

It is revealed from the data in Table (2) that, in general, all the treatments depressed the alkaline phosphatase activity, except the treatments of gamma ray at $100 \mathrm{rad}$ and helium neon at $5.5 \mathrm{~min}$. exposure.

Progesterone treatments enhanced alkaline phosphatase activity gradual with increasing the progesterone dose up to $30 \mathrm{ppm}$, which was about to reach the control level activity and recorded decreased in comparison with the control plants.

The treatment of gamma radiation at $100 \mathrm{rad}$ increased the activity of alkaline phosphatase, it over passed the control by $37.53 \%$ and $38.43 \%$ in the two seasons, respectively.

Helium neon laser rays at $5.5 \mathrm{~min}$. exposure showed the highest alkaline phosphatase activity, which exceeded the control by $4.20 \%$ and $0 \%$ in the two seasons. The same effect was also noticed by [34] showed that, treating of soft wood 
rose cuttings with laser light stimulated enzyme activity in the leaves.

Argon laser rays treatments depressed the alkaline phosphatase activity with all doses, in both seasons.

\subsubsection{Acid Phosphatase ( $\mu \mathrm{g} / \mathrm{ml})$}

Results presented in Table (1) and Table (2) show that, in general, the higher progesterone concentration (30 ppm) increased acid phosphatase activity, as it predominated the control by $85.40 \%$ and $86.95 \%$ over the control in the first and the second season, respectively.

All gamma rays treatments (100 to $250 \mathrm{rad}$ ) increased the acid phosphatase activity. The medium dose (150 rad) showed the higher acid phosphatase activity. It overreached the control by $46.58 \%$ and $30.43 \%$ over the control, in the first and second seasons, respectively.

As for laser rays (helium neon and argon) induced, the lower dose for both of them enhanced the acid phosphatase activity. The increases were $16.45 \%$ and $8.69 \%$ over the control, in helium neon laser rays exposure while it was $53.72 \%$ and $102.02 \%$ over the control in case of argon laser rays.

The medium and higher doses in case of helium neon and argon laser rays induced the higher acid phosphatase activity. The increases over passed $30.43 \%$ and $65.21 \%$ over the control in case of helium neon laser rays at exposure time 5.5 min. and surpassed $100.31 \%$ and $152.17 \%$ over the control for argon laser rays at exposure time $7.5 \mathrm{~min}$. treatment. As for the third laser time exposure, it overreached $77.01 \%$ and $43.47 \%$ over the control for helium neon at $11.5 \mathrm{~min}$. exposure, where it exceeded $124.53 \%$ and $167.24 \%$ over the control in case argon laser irradiation treatment during both seasons, respectively. Similar effect was also noticed by [34] who showed that, soft wood rose cuttings exposed to laser light stimulated enzyme activity in the leaves.

\subsection{Protein $(\mathrm{mg} / \mathrm{ml})$}

Table (2) explains that, progesterone at $30 \mathrm{ppm}$ increased protein concentration as compared to untreated plant leaves. It predominated the control by $42.16 \%$ and $1.30 \%$ over the control during both seasons, respectively.

Gamma rays treatments showed no clear trend as compared to untreated leaves. These results confirmed by the finding by [35] on Phaseolus vulgaris.

The medium and higher doses of helium neon laser irradiation resulted in slight increased protein concentration. Helium neon at exposure time $5.5 \mathrm{~min}$. radiation overreached the control by $6.50 \%$ and $8.27 \%$ over the control. Whereas, at $11.5 \mathrm{~min}$. exposure irradiation surpassed by $9.39 \%$ and $4.79 \%$ over the control during both seasons, respectively.

The third irradiation dose with argon laser rays at 15.5 min. exposure increased the protein concentration. The increases surpassed the control by $0.72 \%$ and $6.31 \%$ over the control in the two seasons, respectively. [36] also noticed similar effect on Salvia officinalis, she found that exposed wet seeds to He-Ne laser gave a higher significantly effect on protein content.

Table 2. Effect of progesterone, gamma, helium neon and argon laser irradiation on enzyme activities in leaves of Gerbera jamesonii plants, during the two seasons of 2006 and 2007.

\begin{tabular}{|c|c|c|c|c|c|c|c|c|c|c|}
\hline \multirow{2}{*}{ Treatments } & \multicolumn{2}{|c|}{ POD (Eu/mg protein) } & \multicolumn{2}{|c|}{ CAT (Eu.g.f.wt) } & \multicolumn{2}{|c|}{ Alk.phosph $(\mu \mathrm{g} / \mathrm{ml})$} & \multicolumn{2}{|c|}{ Acid.phosph $(\mu \mathrm{g} / \mathrm{ml})$} & \multicolumn{2}{|c|}{ Protein $(\mathrm{mg} / \mathrm{ml})$} \\
\hline & $1^{\text {st }}$ & $2^{\text {nd }}$ & $1^{\text {st }}$ & $2^{\text {nd }}$ & $1^{\text {st }}$ & $2^{\text {nd }}$ & $1^{\text {st }}$ & $2^{\text {nd }}$ & $1^{\text {st }}$ & $2^{\text {nd }}$ \\
\hline Cont & 24.14 & 28.28 & 99.82 & 84.37 & 13.08 & 14.18 & 3.22 & 3.45 & 0.415 & 0.459 \\
\hline $\operatorname{Prog}_{1}$ & 30.54 & 14.14 & 125.88 & 126.98 & 5.45 & 5.45 & 4.50 & 5.25 & 0.448 & 0.451 \\
\hline $\operatorname{Prog}_{2}$ & 45.73 & 63.82 & 91.30 & 86.95 & 8.18 & 8.72 & 2.25 & 2.10 & 0.332 & 0.333 \\
\hline $\operatorname{Prog}_{3}$ & 29.85 & 34.61 & 55.42 & 65.62 & 12.54 & 12.54 & 5.97 & 6.45 & 0.590 & 0.465 \\
\hline$\gamma_{1}$ & 36.09 & 17.65 & 96.29 & 95.08 & 17.99 & 19.63 & 3.45 & 4.20 & 0.387 & 0.465 \\
\hline$\gamma_{2}$ & 53.21 & 36.13 & 73.45 & 71.64 & 6.54 & 7.09 & 4.72 & 4.50 & 0.428 & 0.437 \\
\hline$\gamma_{3}$ & 55.21 & 13.28 & 64.28 & 53.96 & 10.90 & 8.72 & 4.20 & 3.75 & 0.407 & 0.479 \\
\hline $\mathrm{He}-\mathrm{Ne}_{1}$ & 28.74 & 26.27 & 47.05 & 46.37 & 7.09 & 7.09 & 3.75 & 3.75 & 0.486 & 0.457 \\
\hline $\mathrm{He}-\mathrm{Ne}_{2}$ & 41.91 & 45.45 & 49.18 & 41.79 & 13.63 & 14.18 & 4.20 & 5.70 & 0.442 & 0.497 \\
\hline $\mathrm{He}-\mathrm{Ne}_{3}$ & 40.13 & 47.07 & 41.26 & 29.85 & 8.72 & 8.72 & 5.70 & 4.95 & 0.454 & 0.481 \\
\hline $\mathrm{Ar}_{1}$ & 52.97 & 20.16 & 64.91 & 50.79 & 8.18 & 8.72 & 4.95 & 6.97 & 0.409 & 0.484 \\
\hline $\mathrm{Ar}_{2}$ & 29.08 & 59.51 & 56.45 & 48.38 & 10.90 & 10.90 & 6.45 & 8.70 & 0.449 & 0.449 \\
\hline $\mathrm{Ar}_{3}$ & 47.33 & 37.33 & 56.89 & 44.11 & 6.54 & 7.09 & 7.23 & 9.22 & 0.418 & 0.488 \\
\hline
\end{tabular}

Prog. : Progesterone prog. $1: 10 \mathrm{ppm}_{\operatorname{prog}} 2: 20 \mathrm{ppm}_{\text {prog }}: 30 \mathrm{ppm}$

$\gamma$ : Gamma radiation $\gamma_{1}: 100 \operatorname{rad} \gamma_{2}: 150 \operatorname{rad} \gamma_{3}: 250 \mathrm{rad}$

$\mathrm{He}-\mathrm{Ne}$ : helium-neon $\mathrm{He}-\mathrm{Ne}_{1}: 1 \mathrm{~min}$. He-Ne $2: 5.5 \mathrm{~min}$. He- $\mathrm{Ne}_{3}: 11.5 \mathrm{~min}$.

$\mathrm{Ar}$ : Argon $\mathrm{Ar}_{1}: 1 \mathrm{~min} . \mathrm{Ar}_{2}: 7.5 \mathrm{~min} . \mathrm{Ar}_{3}: 15.5 \mathrm{~min}$.

\section{General Discussion}

The present investigation aims to study the effect of gamma and laser irradiations and progesterone treatments on some chemical constituents of leaves gerbera plant.

The results in present experiment reveal that progestron increased catalase, peroxidase and acid phosphatase enzymes activity but had no/or slight effect on alkaline phosphatase enzyme. This observation could be correlated with the finding of [37] who considered that BRs implicating in increasing the rate of dark $\mathrm{CO}_{2}$ fixation, reliable indication of the rate of cytoplamic malate synthesis via phosphoenol 
Pyru-vate (PEP) carboxylase, which BRs did not substantially affect peroxidase and phenol activities in many beans [38]. However [39] concluded that BRs enhancing the activation state of some enzymes.

In this investigation results also showed that progesterone treatment at $10 \mathrm{ppm}$ led to increase in the endogenous hormone IBA, cytokynine, whereas, the higher concentration applied at 20 and /or $30 \mathrm{ppm}$ showed a promative effect on both GA and IAA. [40] recorded similar direction that, BRs overcoming the effectiveness of GA and that brassinolide may not directly afford this gibberellins biosynthesis but may promote water uptake into the seeds and leakage of inhibitors excudates form the seeds. In addition, brassinolide may promote the movement of GA within the seeds. However [41] added that brassinosteroids change the balance of other endogenous phytohormones such as IAA, ABA, GA and ethelene. It has also suggested that the effect brassinosteroids are mediated through auxins or that brassinosteroids increased tissue sensitivity to endogenous auxins [42]. Authors also added that brassinosteroids have a synergestic effect with auxins, but the action of brassinosteroids was not related to synthesis of IAA metabolism [43].

So [7] reported that, low dose gamma radiation may induce growth stimulation by changing the hormonal signaling net work in plant cells or by increasing the antioxidant capacity of the cell to easily overcome daily stress factors such as fluctuations of light intensity and temperature in the growth condition.

The data also reveal that gamma at dose of $150 \mathrm{rad}$ increased IAA, GA-like substances, and cytok. and ABA concentration in gerbera leaves. The stimulatory effect of gamma on growth by changing the hormonal signaling net work in plant cells [7]. In view of this fact it could be thought that increments of growth parameters of treated plants with gamma rays may be due to the increase of natural hormone. Where [44] recorded that the increase in wheat productivity by $\mathrm{ABA}$ treatments may be due to the increase in rate of translocation of photosynthesis from leaves to grains. The ABA concentration in wheat plant tissue directly affected crop productivity [45], also [46] recorded that ABA increased movement of photosynthetic assimilate from flage leaves of wheat towards spikes resulting in higher yield compared with untreated plant. It has also been found in the results of this investigation that gamma treatment decrease catalase activity in gerbera leaves tissue while it increased the activity of acid phosphatase. The low doses of $100 \mathrm{rad}$ gamma showed a promotive effect on activity of both enzyme POD and alkaline phosphatase.

It is evident that the promotive effect of gamma irradiation on explain the increase in growth criteria of treated plants where it is known that POD among antioxidant enzymes played an important role of $\mathrm{H}_{2} \mathrm{O}_{2}$ detoxification in cells, thereby protecting cellular components, is also required essentially for different cellular function such as lignification, suberization, cell elongation, growth, regulation of cell wall biosynthesis [47, 48, 49].

In regard to later view it is evident that gamma rays has a promotive effect on some enzyme activity which are usually associated with certain metabolism and anabolic processes which affected directly or indirectly on the growth. The mean values of the previous parameters surpassed those obtained under each single treatment of gamma and progesterone.

Laser radiation of different wavelength and different exposure time $\mathrm{He}-\mathrm{Ne}$ and $\mathrm{Ar}$, which used in this study showed different effect on gerbera plants. Statistical analysis of this work reveal that, the endogenous content of GA, the main biological active GA formation is promoted by red light treatment [50]. This means that the complex cycle of GA promoted by red light, which induced $\mathrm{GA}_{3} \mathrm{~B}$ hydroxylase gen, S3hi expression. This expression is inhibited by far red light treatment. This means that monochromatic light is the only possible way to promote GA B hydroxyls gen S3hI expression. So red light laser $(\mathrm{He}-\mathrm{Ne})$ can induce this effect but not polychromatic light (sunlight). This work support our first opinion about the relation of He-Ne laser (red light laser) and GA formation. Thus the monochromatic red light can only enhance $\mathrm{GA}_{3} \mathrm{~B}$ hydroxylase $\mathrm{S}_{3}$ hi gen expression to form endogenous GA in enough amount, while incoherent light like sunlight inhibit this process because it contain far red light which inhibit the $\mathrm{GA}_{3} \mathrm{~B}$ hydroxylase $\mathrm{S}_{3} \mathrm{hI}$ gen expression.

Laser treatments $\mathrm{He}-\mathrm{Ne}$ and argon led to increase IAA, GA, Cytokinin and ABA concentrations in leaves of gerbera plants. In this respect [50] mentioned that the complex cycle of gibberellic formation is promoted by red light. This induction of GA induced formation of protolytic enzymes that would be expected to release tryptophan precursor of IAA [51]. So it means that laser enhanced GA formation and encourage the release of IAA which had promotive effect on root growth, nutrient and water uptake and this reflected in plant growth. Also GA frequently increases auxins content and may be transport auxin to their site of action [52].

It is evident from results of this investigation that both type of laser He-Ne and argon treatments increased activities of proxidase and acid phasphatase and decreased catalase and alkaline phosphatase.

However, there are reverse relationship between amount of auxins and some enzymes [53]. This observation hold true with our results concerning the increase in IAA, ABA, GAlike substances and the decrease in catalase and alkaline phasphatase activity. It is also evident from the results that laser exposure enhanced GA production. GA effect cell elongation by induction of some enzymes [54].

Also may be laser treatments induced a stress condition on plant which led to increase in acid phosphatase activity. In this respect, [55] recorded that imposition of water logging treatment resulted in a significant increase in acid phosphatase activity.

\section{Conclusion}

Finally, it could be that gerbera plants treated with progesterone resulted increase in protein conc.,peroxidase, acid phosphatase activity and decreased alkaline phosphatase 
(alk.phosph) activity. Low exposure time of argon and /or $\mathrm{He}-\mathrm{Ne}$ laser has promotive effect on growth regulators and POD enzyme activity.

\section{References}

[1] Lebouef, M.; Cave, A. and Goutarel, R. (1964): Alkaloides steroidiques presence de la progesterone dans les feuilles de le Holarrhena floribunda (G. Don) Dur. et Schinz. Compt. Rend. Acad. Sci. Paris 259: 3401-3403. (c.f. Phytochemistry 68 (2007).

[2] Gawienowski, A. M. and Gibbs, C. C. (1968): Identification of cholesterol and progesterone in apple seeds. Steroids, 12: 440-545.

[3] Lino, M.; Nomura, T.; Tamaki, Y.; Yamada, Y.; Yoneyama, K.; Takeuchi, Y.; Mori, M.; Asami, T.; Nakano, T. and Yokota, T. (2007): Progesterone: its occurrence in plants and involvement in plant growth. Phytochemistry, 68 (12): 1664-1673.

[4] Janeczko, A. and Filek, W. (2002): Stimulation of generative development in partly vernalized winter wheat by animal sex hormones. Acta Physiol. Plant, 24: 291-295.

[5] Janeczko, A.W.; FilekBiesaga K. J.; Marcinska, I. and Janeczko, Z. (2003): The influence of animal sex hormones on the induction of flowering in Arabidopsis thaliana comparison with the effect of 24 epibrassinolide. Plant Cell, Tissue and Organ Culture 72: 147-151.

[6] Mucip, G.; Hulya, T. and Serkan, E.( 2013): Exogenous progesterone application protects chickpea seedlings against chilling-induced oxidative stress. Acta Physiol Plant, 35: 241251.

[7] Kim, J.H.; Kim, M.H.; Beak Chung, B.Y.; Wi, S.G. and Kim, J.S. (2004): Alterations in the photosynsetic pigments and antioxidant machineries of red peper (Capsicum annuum L.) seedlings from gamma irradiated seeds. J.plant Biol.47: 314321.

[8] Kovacs and Kereszies (2002): Effect of gamma and UV-B/C radiation on plant cell. Micron, 33: 199-210.

[9] Wi, S. G; Chung, B. Y.; Kim, J. H.; Beak, M. H.; Yang, D. H.; Lee, J. W and Kim, J. S. (2005): Ultrastuctural changes of cell organelles in Arabidopsis stem after gamma irradiation, J. Biol., 48 (2): 195-200.

[10] Berns, M.W.; Nelson, T. S. and Wright, W. H. (1992): Laser physics and laser Tissue Interactions. Laser in Plastic Surgery and Dermatology (B.M. Achouer, V. Mender and M. W. Bernseds). 2nd ed. 1-10, New York.

[11] Pick, R. H. (1993): Using laser in clinical dental practice JADA, 124: 37-47. (c.f. M.Sc.Thesis, National Institute of laser. Cairo Univ.)

[12] Maamoun, M.K.M.; El-Mahrouk, M.E.; Dewir, Y.H. and Omran, S.A. (2014): Effect of radiation and chemical mutagens on seeds germination of black cumin (Nigella sativa L). Journal of Agricultural Technology, 10(5): 1183- 1199.

[13] Glenn, T.L.; Kuo, C.C.; Durly, R.C. and pharis, R.P. (1972): Use of insoluble polyvinyl pyrrolidone for purification of plant extracts and chromatography of plant hormones. Phytochemistry, 11: 345-351.
[14] Van Staden, J. (1973): Changes in endogenous cytokinine levels during abscission and senescence of streptocarpus leaves. J. of Exp. Bot. 21: 667-673.

[15] Vitoria, A. P.; Lea, P. J. and Azevado, R. A. (2001): Antioxidant enzymes responses to cadmium in radish tissues. Phytochemistry, 57: 701-710.

[16] Chance, B. and Moehly, A.C. (1955): Assay of Catalase and Peroxidase. Methods in Enzymology, 2: 762-755.

[17] Amako, A.; Chen, K. and Asada, K. (1994): Separate assays specific for ascorbate peroxidase and guaiacol peroxidase and for the chloroplastic and cytosilic isoenzymes of ascorbate peroxidase in plants. Plant Cell Physiology, 35: 497-504.

[18] Layne, E. (1957): Spectrophotometric and Turbidimetric Methods for Measuring Proteins. Methods in Enzymology. 10: 447-455.

[19] Sebanek, J.; Kralik. J.; Hudeova, M.; Klicova; Slaby, K.; Psota, V.; Vitkova, H.; Polisenka, M.; Kudova, D.; Sterba, S. and Vancura, J. (1989): Growth and hormonal effects of laser on germination and rhizogenesis in plants. Providovedna Prace Ustavu Ceskoslovenske Akademie Ved V Brne., 23(9): 49-69.

[20] Batov, I. and Kitin, P. (1993): Results of laser treatment of ripe cuttings of Robinia Pseudoacacia. Nauka Za Gorata, 30(3): $10-21$

[21] Awad, A. R.E and El Bahr, K. M. (1986): Growth regulators and gamma irradiation treatments affecting the sprouting and endogenous hormones in gladiolus. Acta Horticulture, No.177, vol.II, 612.

[22] Gaber, A.M; Mostafa, H.A.M. and Ramadan, A.A. (2000): Effect of gamma irradiation of faba bean (Viciafaba) plant on its chemical composition, favism causative agents and hormonal levels. Egyptian Journal of Physiological Sciences, 24 (1): 1-16.

[23] Guo, J.; Liu, Y.; Tang, J. and Liu, C. (1983): Mutations in roses induced by gamma rays. Journal of Nanjing Technological College of Forest Products, No.2: 68-74.

[24] Ebtihal, M. AE. (2008): Physiological effects of some phytoregulators on growth, productivity and yield of wheat plant cultivated in new reclaimed soil. Ph.D. Thesis. Collage of Women for Arts, Science and Education. Ain Shams Univ.

[25] Frylink, L. Dubery, I. A and Schabor, J.C. T. (1987): Biochemical changes involved in stress response and ripening behavior of gamma irradiated mango fruit. Photochemistry, 26 (3): 681-686.

[26] Kamel, H.A. (2009): Effects of seed irradiation on $\mathrm{c}^{14}$ fixation and antioxidant activity of vitamin $\mathrm{C}$ and total phenols of canola leaves. Isotope and RAD. RES. 404 (suppl.1), 1353-1361.

[27] Dae, Y. K.; Min, J. H.; Cheong, S. P. and Yong, W. S. (2015): The effects of chronic radiation of gamma ray on protein expression and oxidative stress in Brachypodium distachyon. International Journal of Radiation Biology, 91(5): 407-419.

[28] Jain, J. and Khanna, V.K. (1986): Effect of gamma radiation on peroxidase activity in developing grains of triticale. Indian Journal of Plant Physiology, 29 (4): 308-311.

[29] Nigmanov, V.A.; Pak, V.M. and Kurnetsova, O.N. (1989): The radio protective effect of magnesium chloride on radix enzyme activity and chlorophyll contents in cotton plants. Uzbekiston Biolagija Zurnali, 2: 3-5. 
[30] Liu Qinglin; Wu DiXin; Tian YanTing; Liu QL; Wu DX; Tian, YT (2000): Preliminary report on induced mutation of Iris somaclonals. Acta Horticulturae, No.404: 91-94.

[31] Ahmed, S. O. I. (2004): Biochemical changes of potatoes during growth and storage as affected by gamma radiation Ph.D. Thesis, Department of Biochemistry. Faculty of Agric. Cairo, Univ.

[32] Moussa, H.R. (2008): Gamma irradiation affects on antioxidant enzymes and G6PDH activities in Vicia faba plants. Journal of New Seeds, 9(1): 89-99.

[33] Zong BoQiu; Xiaoliu; Xiang Jun; Tian; and Ming Yue. (2008): Effect of $\mathrm{Co}_{2}$ laser pretreatment on drought stress resistance in wheat. Journal of Photochemistry and Photobiology, 90: 1725 .

[34] Grisyuk, S. N. (1985): Effect of laser light on rooting of rose cuttings. Introduktsiya AKK limatizatsiya Rastenii, No.3: 5152.

[35] Beltagi, M.S.; Ismail, M.A and Mohamed, F.H. (2006):Induced salt tolerance in common bean (Phaseolus vulgaris L.) by gamma irradiation. Pakistan Journal of Biological Sciences, 9(6): 1143-1148.

[36] Wessam, M. S. E. A. (2005): Effect of laser on the growth and on the active constituents of sage plant. M.Sc. Thesis, National Institute of laser. Cairo Univ.

[37] Kalinich, J.F.; Mandava, N.B. and Todhunter, J.A. (1985): Relationship of nucleic acid metabolism to brassinolide induced responses in beans. J. Plant Physiol, 120: 207-14.

[38] Blushan, N. (1988): Plant growth promoting brassinosteroids. Plant Physiol., 39: 23-52.

[39] Braun, P. and Wild, A. (1984a): The influence of brassinosteroid on growth promoting steroidal lactone on development and carbon dioxide fixation capacity of intact wheat and mustard seedlings. In Advances in Photosynthesis Research, Proc. 6th Cong. photosynthesis, cd. Sybesna, 3: 461-464.

[40] Yasutomo Takeuchi; Yumi Omigawa; Masaru; Ogasawara; Koichi Yoneyama; Makoto Konnai and Douglas Worsham, A. (1995): Effects of brassinosteroids on conditioning and germination of clover broomrape Orobanche minor seeds. Plant Growth Regulation, 16: 153-160.

[41] Krizek, D.T. and Mandova, N.B. (1983): Influence of spectral quality on the growth response of intact bean plants to brassinosteroid, a growth promoting steroidal lactone, 7 stem elongation and morphyegenesis. Physical Plant, 57: 317-323.

[42] Mandava, N.B. (1988): Plant growth promoting brassinosteroids. Ann. Rev. Plant Mol, 39: 23-52.

[43] Cohen, J.D. and Meudt, W.J. (1983): Investigations on the mechanism of brassinosteroid response. I. Indol 3 acetic acid metabolism and transport. Plant Physiol., 72: 691-694.

[44] Ray, S. and Choudhuri, M. A. (1981): Effect of growth regulators on grain and yield of rice Oryza Sativa L. Ann. Bol. (London) 47, 755.

[45] Innes, P.; Black Well, R.D. and Quarrie, S.A. (1984): Some effects of genetic variation in drought induced abscisic acid accumulation on the yield and water use of spring wheat. J. Agric. Sci. 102, 341.

[46] Dewdeny, S.J. and Mcwha, J.A. (1979): Abscisic acid and the movement of photosynthetic assimulates towards developing wheat (Triticum aestivium) grains. Z. Phamzen, Physiol. 92: 183 .

[47] Chanda, E. and Singh, H. (1997): Changes in peroxidase and IAA oxidase activities during wheat grain development. Plant Physiol. Biochem, 35: 245-250.

[48] Espelie, K. E.; Francesci, V.R. and Kolattukudy, P.E. (1986): Immuno cytochemical localization and time course of appearance of an anionic peroxidase associated with suberization in wound healing potato tuber tissue. Plant Physiol, 81: 487-492.

[49] Lagrimini, L.M.; Burkhat, W. and Moyer, M. (1987): Molecular cloning of complementary DNA encoding the lignin forming peroxidase from tobacco molecular analyses and tissue specific expression, Proc. Natl. Acad. Sci. USA 84: 7542-7546.

[50] Kamiya, Y.L. Jose and Martinez, G. (1999): Regulation of gibberellin biosynthesis by light. Current Openion in Plant Biology, 2: 398-403.

[51] Van and Overbeek, J. (1966): Plant hormones and regulators science. U.S.A. 152: 721-731. W.H. Freeman and Company, San Francisco. (c.f. M.Sc. Thesis, National Institute of laser. Cairo Univ.)

[52] Kuraishi, S. and Muir, K.M. (1963): Mode of action of growth retarding. Plant Physiol., 38: 19-24.

[53] Katsumi, M. and Sano, H. (1968): Changes in indole acetic oxidase levels in leaves of Begonia evansiana as they ages. Plant Cell Physiol, 15: 869.

[54] Macleod, A. M. and Millar, A. S. (1962): Effect of gibberellic acid on basley endosperm. J. Inst. Brewing 66: 322-332. W.H. Freeman and Company, San Francisco. U.S.A. (c.f. M.Sc. Thesis, National Institute of laser. Cairo Univ.)

[55] Arun Dev Sharma, Neha, S. and Jagjeet. K. K. (2005): Short term water legging induced changes in phosphatase activities in shoots and roots of sorghum seedlings role of phosphatases during water logging in relation to phosphatases. Plant Physiology, 3(1-2): 71-79. 